\title{
Väärennetyt asiakirjat ja sivistystyön valvonta
}

Jussi Pikkusaari käy Aulis Alasen innoittamana käsiksi tärkeisiin asioihin (Aikuiskasvatus 4/86). Vapaan sivistystyön, aikuiskasvatuksen ongelmia on todella ruvettava rehellisesti pohtimaan. Muuten asianomaiset järjestelmät joutuvat ja joutavatkin historian romukoppaan.

Pikkusaari toteaa avoimesti: "Eivät yhdistykset ja järjestöt, jotka muodostavat sivistysjärjestöjen asiakaskunnan ole välttämättä pulmusia. Houkutus valtionapujen hankkimiseen väärennetyillä asiakirjoilla mihin tahansa toimintaan voi kasvaa vastustamattomaksi." Tässä on liioittelua, tuskin asiakirjoja tahallaan väärennetään, mutta tiettyä omantunnon venyttämistä saattaa ilmetä. Esimerkiksi siten, että puolueen paikallisyhdistyksen kokous merkitään samalla opintokerhon kokoukseksi tai kurssiksi. Ehkä niinkin, että kun on iso kokous, siitä saadaan jakolaskulla useitakin kerhoja. Yhdistyksen opintosihteeri käy jaakobinpainia: ainahan kokouksissa pohditaan yhteiskunnallisia asioita, oppimistakin tapahtuu. Eikö kaikki yhdistystoimnta ole sitäpaitsi mitä parhainta yhteiskunnallisten asioiden opiskelua?

Kipeän ongelman rohkea esille ottaminen on kiitettävä asia, mutta sitten Pikkusaari erehtyy eräissä asioissa. Ensinnäkään hän ei suostu millään ymmärtämään mitä Alanen puhuu valtiollistamisesta.

Alanen on myös aivan oikeassa todetessaan opintojen käpertymisen ahtaaksi järjestökoulutukseksi. Se on järjestöaktivistien keskinäistä taktiikan hiontaa yms. Pikkusaari puhuu myyttisestä rivimiehestä, "joka on aina vilpitön". Pelkkää myyttiä on myös fraseologia kansanliikeyhteiskunnasta. Yleisesti on todettu kansalaisten vieraantuminen puolueista. Vieraantumisen syynä on juuri se, että puolueet ovat menettäneet kansanliikeluonteensa. Niistä on tullut hallintokoneiston melko kiinteä osa. Raivoisa hyökkäys kokoomusta vastaan on kohtuuton, sehän on samanlainen "kansanliike" kuin demaritkin, järjestöllisine sivistystöineen kaikkineen.
Pikkusaari huutaa apuun tehokasta valvontahallintoa ja viranomaisia tekemään pistokokeita. Tämä kauhistuttaa minua. Esimerkiksi lääninhallituksen kouluosastojen ja kouluhallituksen työssä ei enää mielellään puhuta valvonnasta. Nykyaikainen hallintoajattelu korostaa luottamusta ja sen pohjalle rakentuvaa ohjausta.

Valtion viranomaiset luottavat varsin pitkälle kansalaisopistojen, kirjastojen ja kansanopistojen sisäiseen hallintoon. Eikö opintokerhojen kohdallakin olisi parempi etsiä sellaisia järjestelyjä, jotka jo rakenteeltaan rakentavat luottamusta? Muilla vapaan sivistystyön sektoreilla tärkein tekijä tähän suuntaan on varmasti julkisuus.

Mutta voidaanko järjestöllinen sivistystyö tehdä julkiseksi? Tuskin. Niinpä olisikin parempi etsiä valtionavuille muita kuin nykyiseen pääluvun laskentaan pohjautuvia perusteita.

Koska järjestöjen opintotoimintaa on mahdotonta erottaa niiden muusta toiminnasta, voitaisiin yksinkertaisesti luopua erillisestä opintotoiminnan tukemisesta. Annettaisiin vain tukea yleishyödyllisiksi katsotuille järjestöille ja nämä sitten itsenäisesti saisivat päättää, miten avustusta mm. opintotoimintaan käyttävät. Huomattavimmat opintokeskukset ovat suurimpien puolueiden orgaaneja, niinpä tilanne kirkastuu huomattavasti, kun lisätään puoluetukea vastaavalla summalla kuin mitä nyt menee opintokeskusten tukemiseen.

"Vasta opintokeskuslaki varsinaisesti loi organisatoorisesti järjestöllisen sivistystyön maassamme" kirjoittaa Pikkusaari ja Alanen aivan oikein kiistää tämän. Aitoa opintotoimintaa oli nimenomaan ennen nykyisiä lakeja. Pikemminkin juuri uudistus teki "rahankeruun bulvaaneja" ja "rahankeruuautomaatteja". Toiminnan ehdot alettiin sanella muista vaatimuksista kuin opinnollisista käsin.

"Esimerkiksi Työväen Sivistysliitolla on noin 10000 yhdistystä valvottavanaan" sanoo Pikkusaari ja haluaisi kaataa työn valtionhallinnolle. Ei tule mitään. Pitäisikö esimerkiksi lää- 
ninhallituksen kouluosaston virkamiesten ruveta kulkemaan puolueosastojen ja muiden yhdistysten kokouksissa nuuskimassa? Kiitos ei. Kyllä lähtökohdan täytyisi olla luottamus, yhteistyö ja muut todella myönteiset asiat eikä rötösjahti. Vai lykättäisiinkö väärinkäytösten siunaaminen synniksi tyhmille virkamiehille, jotka virkahuoneessaan tutkivat paperivuoria ja lyövät niihin "hyväksytään" leimoja?
Eräs järjestöllisen sivistystyön toimitsija sanoi yhdessä seminaarissa taannoin, että nykyinen vapaan sivistystyön järjestelmä on täysin mätä. Ymmärtäisin Pikkusaaren kirjoituksen viime kädessä tuskan huudoksi, joka ilmaisee samoja tuntoja. Se on kuitenkin myös lupaus paremmasta: maailman parantaminen alkaa tosiasioiden tunnustamisesta. 